\title{
Biodiversity and biogeographic relationships of the polychaete fauna in French Atlantic and Mediterranean waters
}

\author{
JEAN-CLAUDE DAUVIN $^{1}$, GUY BACHELET ${ }^{2}$ and GERARD BELLAN ${ }^{3}$ \\ ${ }^{1}$ UMR 8013 CNRS ELICO, Université des Sciences et Technologies de Lille Station Marine de Wimereux 28 avenue \\ Foch, B.P. 80, F-62930 Wimereux, France.E-mail: dauvin@ pop.univ-lille1.fr \\ ${ }^{2}$ UMR 5805 CNRS EPOC, Université Bordeaux 1, Station Marine d'Arcachon, 2 rue du professeur Jolyet, \\ F-33120 Arcachon, France \\ ${ }^{3}$ UMR 6540 CNRS DIMAR, Université de la Méditerranée, Station Marine d'Endoume rue de la Batterie des Lions, \\ F-13007 Marseille Cedex, France,
}

SUMMARY: A survey of the literature, including the recent systematic reviews, reveals that 934 polychaete species have been recorded in French Atlantic (including the English Channel) and Mediterranean marine waters, including 818 species living on the continental shelf and 116 species that are strictly bathyal. These 934 species belong to 71 families, among which the Syllidae is the most diverse (97 species), followed by the Serpulidae (69 species), Spionidae and Phyllodocidae, each with more than 40 species. Forty-four families have fewer than 10 species recorded in each. The total number of species is spread over 11 continental shelf areas as well as the Atlantic and Mediterranean bathyal depths. In terms of species diversity, the richest areas are the Mediterranean coasts of Provence-Côte d'Azur (507 species) and Languedoc-Roussillon (483 species), the western part of the English Channel (402 species), and the southern part of the Bay of Biscay (343 species). The lowest numbers of species were recorded in the eastern English Channel, due to an impoverishment of all the fauna in this part of the Channel. Other areas - for example, the Iroise Sea, the coast of Corsica and Mediterranean bathyal depths also show low numbers, but this may only reflect the fact that insufficient information about these areas is available. A similarity analysis of 13 areas distinguishes four distinct faunal groups, each specific to one of four general locations: (1) the bathyal Atlantic and Mediterranean zones, including the coast of Corsica, (2) the two Mediterranean coastal areas (ProvenceCôte d'Azur and Languedoc-Roussillon), (3) the four zones of the Atlantic continental shelf, and (4) the English Channel. The combined species can be separated into 17 different biogeographic groups.

Keywords: Annelida, Polychaeta, French coastline, inventory, distribution, biodiversity.

RESUMEN: BIODIVERSIDAD Y RELACIONES BIOGEOGRÁFICAS DE LA FAUNA DE POLIQUETOS DE LAS AGUAS FRANCESAS ATLÁNTICAS Y MEDITERRÁNEAS. - Un total de 934 especies de poliquetos han sido censadas para las aguas marinas Francesas Mediterráneas y Atlánticas (incluyendo el canal de la Mancha) en base al desarrollo de una reciente búsqueda bibliográfica que incluye las últimas revisiones sistemáticas. De estas, 818 especies pertenecen a aguas de la plataforma continental y 116 especies son estríctamente de aguas batiales. Las 934 especies pertenecen a 71 familias, de entre las cuales los sílidos es la familia más diversificada (97 especies) seguidos por los serpúlidos (69 especies), y espiónidos y filodócidos, cada uno con una cuarentena de especies. Cuarenta y cuatro de las familias identificadas lo hicieron con menos de diez especies. Este censo ha sido efectuado sobre 11 áreas de la plataforma continental, así como los fondos batiales Mediterráneos y Atlánticos. En términos de diversidad de especies, las áreas más ricas fueron las costas Mediterráneas de la Provence-Costa Azul (507 especies) y el LanguedocRoussillon (483 especies), la parte Occidental del canal de la Mancha (402 especies), y la parte Sur de la Bahía de Vizcaya (343 especies). Los números más bajos fueron alcanzados en la parte Oriental del canal de la Mancha debido a un empobrecimiento de la fauna en esta zona. Otras zonas como por ejemplo, el Mar Iroise, la costa de Córcega y los fondos batiales Mediterráneos, muestran asimismo números pobres aunque ello podría tan solo reflejar un déficit de información en estas zona. Un análisis de similitud entre las 13 áreas separa cuatro grupos diferentes, cada uno incluyendo de una a cuatro zonas en su agrupación: (1) las zonas batiales Mediterráneas y Atlánticas, incluyendo la costa de Córcega, (2) las dos áreas costeras mediterráneas (Provence-Costa Azul y Languedoc-Roussillon), (3) las cuatro zonas de la plataforma continental Atlántica, y (4) el canal de la Mancha. Las especies obtenidas pueden ser asimismo separadas en 17 grupos biogeográficos diferentes.

Palabras clave: Annelida, Polychaeta, costa francesa, inventario, distribución, biodiversidad. 


\section{INTRODUCTION}

The present census compiles the records of marine polychaetous annelids along the French coasts - from the Belgian border to the Spanish border on the Atlantic and from the Spanish border to the Italian border in the Mediterranean-as well as the bathyal zones of both the Bay of Biscay and the Gulf of Lions. Historically, the first comprehensive lists of polychaetes along the French coast were 'Faune de France: Errantia Polychaeta' and 'Faune de France: Sedentaria Polychaeta' (Fauvel, 1923, 1927). These two books were used to identify polychaetes not only in other European waters, but, given that Fauvel defended the cosmopolitan nature of polychaetes, also elsewhere in the world [e.g. the Kerguelen Islands and other French possessions in the Indian or Pacific Oceans (Fauvel, 1930, 1952)]. Since the publication of Fauvel's books in 1923 and 1927 , polychaetes have been the subject of numerous systematic reviews. At the beginning of the $21^{\text {st }}$ century, for example, Bellan (2001) recorded 1848 marine polychaete species in Europe, including all the species observed along the French coasts, but provided no information on their geographic location. More recently, Dauvin et al. (2003) proposed an updated list of 493 species of polychaetous annelids in the English Channel.

This paper aims (1) to update the list of polychaetous annelids found in French marine waters, and (2) to analyze the biodiversity and the biogeographic relationships between the polychaete faunal groups found in 11 continental shelf areas as well as in Atlantic and Mediterranean bathyal depths.

\section{MATERIALS AND METHODS}

\section{Species census and inventory}

France has $5500 \mathrm{~km}$ of coastline, including 3800 $\mathrm{km}$ along its western and northwestern coasts (Atlantic Ocean, English Channel and North Sea) and $1700 \mathrm{~km}$ around the Mediterranean Sea. (See Dauvin and Bellan-Santini (2004) for a complete description of the main characteristics of the French coastline.)

Published inventories, systematic reviews and biogeographic researches specifically related to polychaetes were used to compile this census. In addition, specific ecological research published by

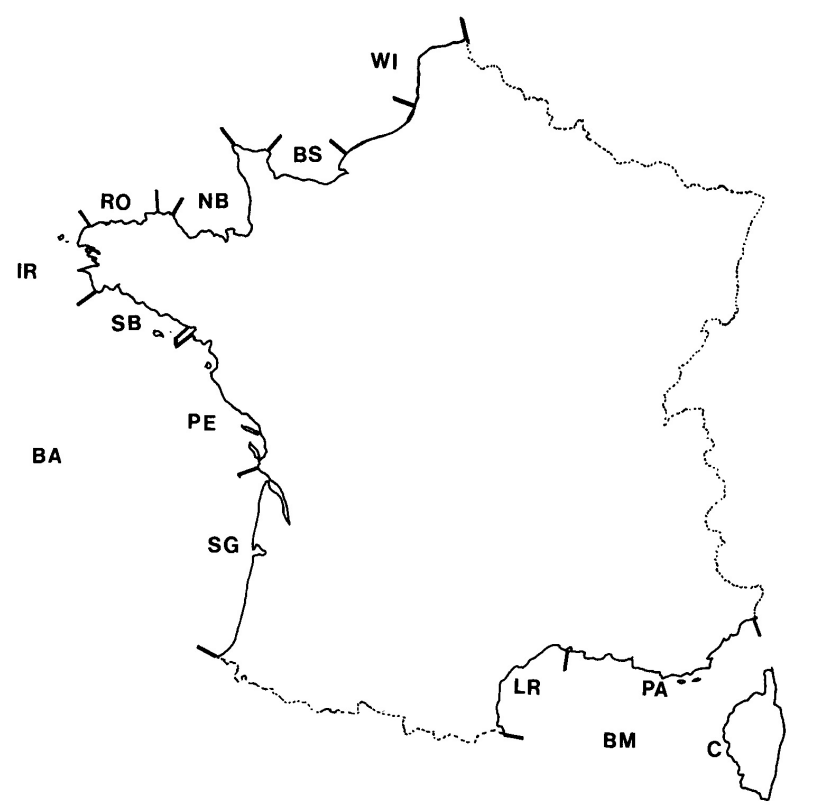

FIG. 1. - Geographic limits of the 13 areas along the French coasts. [SD: Strait of Dover; BS:Bay of Seine; NB: Normano-Breton Gulf; RO: Roscoff area; IR: Iroise Sea; SB: Southern Brittany; PE: Pertuis area; SBB: Southern Bay of Biscay; LR: Languedoc-Roussillon coast; PA: Provence and Côte d'Azur coast; CO: Corsica; BA: Atlantic bathyal zone; BM: Mediterranean bathyal zone].

authors with expertise in polychaete taxonomy was also taken into account. The census encompasses the Atlantic (Bay of Biscay) and Mediterranean (NW Mediterranean Sea) bathyal zones as well as 11 coastal areas (Fig. 1). Data for the English Channel (SD, BS, NB, RO) were extracted from a study by Dauvin et al. (2003) and completed using studies by Desroy (1999) and Ruellet (2004) for an analysis of 150 references. Data for the Bay of Biscay (IR, SB, PE, SBB, BA) were compiled by G. Bachelet from an analysis of 287 references. G. Bellan assembled about 400 references for the Mediterranean (LR, PA, $\mathrm{CO}, \mathrm{BM})$, most of them published since the 1960s.

This census adopts the polychaete family classification system proposed by Fauchald and Rouse (1997) and Rouse and Fauchald (1997), and followed by Hansson (1998).

The lengths of the coastline and the number of habitats following the inventory of French coastal biocenosis by Dauvin et al. (1994) are given for each coastal area. The boundaries of the areas are given below:

- Strait of Dover (SD), from the Belgian border to the Authie River, 12 nautical miles off the coast, $\approx 160 \mathrm{~km}$ and 25 habitats: 224 species;

- Bay of Seine (BS), south of a line running from the Antifer Cape to the Pointe de Barfleur, $\approx 350 \mathrm{~km}$ and 29 habitats: 213 species; 
- Normano-Breton Gulf (NB), east of a line running from La Hague Cape to Bréhat Island, $\approx 450$ $\mathrm{km}$ and 34 habitats: 281 species;

- Roscoff area (RO), from the Seven Islands to the Aber Wrach, 25 nautical miles off the coast, $\approx$ $400 \mathrm{~km}$ and 42 habitats: 402 species;

- Iroise Sea (IR), from Aber Wrach to the Pointe de Penmarch, 25 nautical miles off the coast, $\approx 450$ $\mathrm{km}$ and 46 habitats: 195 species;

- Continental shelf and coast of Southern Brittany (SB), from the Pointe de Penmarch to the Loire estuary, $\approx 650 \mathrm{~km}$ and 54 habitats: 287 species;

- Continental shelf and coast of the 'Pertuis' (PE), south from the Loire estuary to the Gironde estuary, $\approx 450 \mathrm{~km}$ and 40 habitats: 238 species;

- Continental shelf and coast of the Southern Bay of Biscay (SBB), south from the Gironde estuary to the Spanish border, $\approx 300 \mathrm{~km}$ and 32 habitats: 343 species;

- Continental shelf and coast of LanguedocRoussillon (LR), from the Spanish border to the western part of the Rhone river, $\approx 250 \mathrm{~km}$ and 46 habitats: 483 species;

- Continental shelf and coast of Provence and Côte d'Azur (PA), from the eastern part of the Rhone river to the Italian border, $\approx 550 \mathrm{~km}$ and 47 habitats: 507 species;

- Continental shelf around Corsica $(\mathrm{CO}), \approx 800$ $\mathrm{km}$ and 39 habitats: 247 species;

- Atlantic bathyal zone (BA): 331 species;

- Mediterranean bathyal zone (BM): 155 species.

\section{Statistical analyses}

The biogeographic affinity between the polychaete fauna of the French coasts and those of other areas in the North Atlantic was analysed using the Bray-Curtis similarity method (Clarke and Warwick, 1994).

Parsimony analyses were performed using PAUP 3.1.1. (Swofford,1993). Characters were coded for their presence (1) or absence (0) for each of the different geographic areas (OTUs) used before in the biogeography distribution of amphipods (Dauvin and Bellan-Santini, 2004). Tree searches were performed using the heuristic search command ThreeBisection-Reconnection (TBR). Zero length branches were collapsed and MULPARS was activated. Initial MAXTREES setting was 100. An outgroup area coded all 0 s roots the area cladogram as sug- gested by Lambshead and Paterson (1986) and Cracraft (1994). The trees obtained were unique in each analysis. Character transformations were studied using MacClade 3.01. (Maddison and Maddison, 1992). Analysis of character state distributions and optimizations were performed using PAUP and MacCLade programs. A cladogram corresponding to the strict consensus tree was constructed.

\section{RESULTS AND DISCUSSION}

\section{General distribution}

The list available at http://www.com.univmrs.fr/DIMAR/ records the 934 species found in French waters. These species belong to 71 families (Table 1), among which the Syllidae is the most diverse with 97 species, followed by the Serpulidae (69 species) Spionidae (53), Phyllodocidae (40) and Polynoidae (37). Less than 10 species were recorded in each of 44 families. There were 818 species found on the continental shelf $(0-200 \mathrm{~m})$ and 116 species found only in bathyal zones (>200 m). The strictly bathyal species are spread across three families: Fauveliopsidae live in both the Atlantic and Mediterranean bathyal zones, while Trochochaetidae and Siboglinidae are found only in the bathyal depths of the Bay of Biscay.

In terms of species numbers, the Provence-Côte d'Azur area is the most diverse area with 507 species, followed by the Languedoc-Roussillon area with 483 species. The Roscoff area in the western region of the Channel comes next, with 402 species, followed by the South-Biscay area and the Atlantic bathyal zone with 343 and 331 species, respectively. The bathyal zone of the Bay of Biscay shows a species richness twice as high as that of the Mediterranean NW Basin (331 species compared to 155 species). The number of species in the other seven areas ranges from 195 in the Iroise Sea area to 287 in the Southern Brittany area.

Thirty-three percent (312 species) of the total number of species are found in a single area and may be considered 'endemic' to their respective areas. However, this level of endemism should be considered as a crude estimate, as the level of knowledge is insufficient in certain areas, and adjacent areas outside the scope of this study (i.e. borders of Belgium, Spain, and Italy) are not considered. These 'endemic' species occur primarily in the 
TABLE 1. - Number of polychaete species per family on the French side of the Channel (SD + BS + NB + RO); in the entire English Channel; on the French coast of the Bay of Biscay (IR + SB + PE + SBB); in the Bathyal zone of the Bay of Biscay; in the entire Bay of Biscay, including the Spanish coastline and the bathyal depths; along the French Mediterranean coastline (LR + PA + CO); in the Bathyal zone of the Mediterranean Sea; and in the entire Gulf of Lions, including the coastline and the bathyal depths. The last column is the number of strictly continental shelf species.

\begin{tabular}{|c|c|c|c|c|c|c|c|c|c|}
\hline Families & $\begin{array}{l}\text { French } \\
\text { coasts } \\
\text { Channel }\end{array}$ & $\begin{array}{c}\text { Total } \\
\text { Channel }\end{array}$ & $\begin{array}{l}\text { French } \\
\text { coasts Bay } \\
\text { of Biscay }\end{array}$ & $\begin{array}{l}\text { Bathyal } \\
\text { Bay of } \\
\text { Biscay }\end{array}$ & $\begin{array}{l}\text { Total } \\
\text { Bay of } \\
\text { Biscay }\end{array}$ & $\begin{array}{l}\text { French } \\
\text { coasts } \\
\text { Medit. }\end{array}$ & $\begin{array}{l}\text { Bathyal } \\
\text { Medit. }\end{array}$ & $\begin{array}{l}\text { Total } \\
\text { Medit. }\end{array}$ & $\begin{array}{l}\text { Total } \\
\text { French } \\
\text { cont. shelf }\end{array}$ \\
\hline Syllidae & 71 & 76 & 43 & 24 & 105 & 71 & 12 & 71 & 97 \\
\hline Serpulidae & 29 & 37 & 19 & 14 & 35 & 55 & 8 & 57 & 69 \\
\hline Spionidae & 34 & 34 & 38 & 11 & 50 & 40 & 7 & 40 & 53 \\
\hline Phyllodocidae & 30 & 31 & 30 & 10 & 35 & 30 & 3 & 30 & 40 \\
\hline Polynoidae & 20 & 26 & 19 & 29 & 40 & 29 & 7 & 32 & 37 \\
\hline Sabellidae & 22 & 24 & 16 & 15 & 29 & 30 & 2 & 30 & 33 \\
\hline Terebellidae & 21 & 23 & 26 & 16 & 31 & 25 & 6 & 25 & 32 \\
\hline Maldanidae & 15 & 16 & 18 & 13 & 27 & 18 & 8 & 19 & 29 \\
\hline Nereididae & 16 & 16 & 17 & 11 & 27 & 24 & 1 & 24 & 27 \\
\hline Paraonidae & 8 & 8 & 12 & 7 & 20 & 20 & 11 & 22 & 25 \\
\hline Dorvilleidae & 13 & 14 & 14 & 6 & 18 & 7 & 11 & 7 & 20 \\
\hline Cirratulidae & 13 & 15 & 12 & 6 & 16 & 19 & 3 & 19 & 20 \\
\hline Capitellidae & 7 & 8 & 8 & 8 & 13 & 17 & 8 & 18 & 19 \\
\hline Opheliidae & 11 & 11 & 13 & 4 & 17 & 13 & 4 & 13 & 19 \\
\hline Eunicidae & 8 & 8 & 12 & 10 & 17 & 14 & 5 & 15 & 18 \\
\hline Hesionidae & 7 & 8 & 12 & 5 & 17 & 13 & 1 & 13 & 18 \\
\hline Onuphidae & 3 & 5 & 12 & 11 & 16 & 13 & 7 & 14 & 16 \\
\hline Lumbrineridae & 8 & 8 & 10 & 17 & 23 & 13 & 7 & 13 & 15 \\
\hline Orbiniidae & 4 & 4 & 10 & 3 & 12 & 11 & 4 & 12 & 14 \\
\hline Nerillidae & 11 & 12 & 5 & & 5 & 3 & & 3 & 14 \\
\hline Ampharetidae & 4 & 4 & 9 & 14 & 18 & 12 & 7 & 13 & 14 \\
\hline Nephtyidae & 8 & 8 & 7 & 7 & 11 & 11 & 7 & 11 & 13 \\
\hline Sigalionidae & 8 & 8 & 9 & 8 & 12 & 10 & 1 & 11 & 12 \\
\hline Protodrilidae & 10 & 10 & 7 & & 7 & 2 & & 2 & 12 \\
\hline Glyceridae & 8 & 8 & 8 & 6 & 10 & 9 & 5 & 9 & 10 \\
\hline Chaetopteridae & 2 & 2 & 6 & 4 & 6 & 6 & 2 & 6 & 8 \\
\hline Flabelligeridae & 6 & 6 & 6 & 5 & 9 & 8 & 3 & 8 & 8 \\
\hline Arenicolidae & 4 & 4 & 3 & & 6 & 5 & & 5 & 7 \\
\hline Pilargidae & & & 3 & 3 & 5 & 6 & 3 & 6 & 7 \\
\hline Magelonidae & 4 & 4 & 6 & 2 & 7 & 6 & & 6 & 7 \\
\hline Oenonidae & 4 & 4 & 2 & 1 & 2 & 5 & 1 & 5 & 6 \\
\hline Goniadidae & 5 & 5 & 4 & 4 & 6 & 5 & 2 & 5 & 6 \\
\hline Scalibregmatidae & 3 & 3 & 1 & 3 & 3 & 5 & 2 & 5 & 5 \\
\hline Aphroditidae & 3 & 3 & 4 & 5 & 5 & 4 & 2 & 4 & 5 \\
\hline Sphaerodoridae & 4 & 4 & 3 & 7 & 10 & 4 & 2 & 4 & 5 \\
\hline Sabellariidae & 3 & 3 & 3 & 1 & 4 & 4 & 1 & 4 & 5 \\
\hline Diurodrilidae & 3 & 3 & 3 & & 3 & 2 & & 2 & 4 \\
\hline Acoetidae & & & 2 & 1 & 3 & 4 & 2 & 4 & 4 \\
\hline Myzostomidae & & & & & & 4 & & 4 & 4 \\
\hline Pholoidae & 2 & 2 & 2 & 2 & 4 & 3 & 1 & 3 & 4 \\
\hline Ctenodrilidae & 1 & 1 & 1 & & 2 & 4 & & 4 & 4 \\
\hline Pectinariidae & 3 & 3 & 4 & 3 & 4 & 4 & 1 & 4 & 4 \\
\hline Polygordiidae & 3 & 3 & 2 & & 3 & 1 & & 1 & 4 \\
\hline Amphinomidae & 2 & 2 & 2 & 5 & 6 & 2 & 1 & 2 & 3 \\
\hline Alciopidae & & 1 & 1 & & 3 & 2 & & 2 & 3 \\
\hline Chrysopetalidae & & & 1 & 1 & 2 & 3 & & 3 & 3 \\
\hline Spintheridae & 2 & 2 & & & 1 & 1 & & 1 & 3 \\
\hline Oweniidae & 3 & 3 & 3 & 3 & 3 & 2 & & 2 & 3 \\
\hline Trichobranchidae & 2 & 3 & 2 & 1 & 3 & 3 & 1 & 3 & 3 \\
\hline Saccocirridae & 1 & 1 & 2 & & 2 & 3 & & 3 & 3 \\
\hline Cossuridae & 1 & 1 & 1 & 1 & 2 & 1 & & 1 & 2 \\
\hline Euphrosinidae & 1 & 1 & 1 & 4 & 4 & 2 & 1 & 2 & 2 \\
\hline $\begin{array}{l}\text { Pisionidae } \\
\text { lac }\end{array}$ & 1 & 1 & 1 & & 1 & 2 & & 2 & 2 \\
\hline Tomopteridae & 1 & 1 & & & 6 & 1 & & 1 & 2 \\
\hline Poecilochaetidae & 1 & 1 & 2 & 2 & 2 & 2 & 2 & 3 & 2 \\
\hline Acrocirridae & 1 & 1 & & 2 & 3 & 2 & & 2 & 2 \\
\hline Psammodrilidae & 2 & 2 & 1 & & 1 & & & & $\overline{2}$ \\
\hline Histriobdellidae & 1 & 1 & & & & & & & 1 \\
\hline Eulepethidae & & & & & & 1 & & 1 & 1 \\
\hline Iopsilidae & & & & & & 1 & & 1 & 1 \\
\hline Lacydoniidae & 1 & 1 & & & 1 & 1 & 1 & 2 & 1 \\
\hline Lopadorrhynchidae & & & 1 & & 2 & 1 & & 1 & 1 \\
\hline Paralacydoniidae & & & & & & 1 & & 1 & 1 \\
\hline Apistobranchidae & 1 & 1 & & & & 1 & & 1 & 1 \\
\hline Longosomatidae & & & & 2 & 2 & 1 & & 1 & 1 \\
\hline Sternaspidae & & & 1 & 1 & 1 & 1 & 1 & 1 & 1 \\
\hline Parergodrilidae & & & 1 & & 1 & & & & 1 \\
\hline Typhloscolecidae & & & & & 2 & & & & \\
\hline Siboglinidae & & & & 11 & 11 & & & & \\
\hline Trochochaetidae & & & & 1 & 1 & & & & \\
\hline Fauveliopsidae & & & & 1 & 1 & & 2 & 2 & \\
\hline Total & 460 & 495 & 461 & 331 & 754 & 623 & 155 & 641 & 818 \\
\hline
\end{tabular}


Atlantic bathyal zone (103 species), in the two Mediterranean areas [Provence-Côte d'Azur (56 species) and Languedoc-Roussillon (55 species)], in the Roscoff area (38 species), and in the SouthBiscay area (24 species). In the other areas, the numbers of endemic species are very low, varying between 1 and 7 .

Several explanations for the differences in the biodiversity of polychaetes recorded in French territorial waters are possible:

- The number of species in an area may be proportional to the length of the coastline in that area, but there are problems with this explanation. For example, despite its extensive coastline, Corsica $(\approx$ $800 \mathrm{~km}$ ) has one of the lowest polychaete species richness values, while the Languedoc-Roussillon and Provence $(\approx 250 \mathrm{~km})$-Côte d'Azur $(\approx 550 \mathrm{~km})$ areas, whose span of coastline is similar to that of Corsica, exhibit fairly high species diversity.

- Variations in research effort could also be the cause of the diverse results. Perhaps more research in specific areas would result in a higher number of species being recorded for those areas. Some areas-around Corsica and in the Mediterranean bathyal zone, for example-clearly suffer from a lack of polychaete studies. Similarly, knowledge of the northern areas of the Bay of Biscay (Iroise Sea and Southern Brittany) is scanty compared with knowledge of the South Biscay area. Conversely, the presence of the biological stations at Roscoff (RO), Banyuls (LR) and Marseilles (PA) since the end of the $\mathrm{XIX}^{\circ}$ century have had some effects on the high diversity recorded here as a result of numerous benthic studies in the vicinity of these marine stations. As an illustration of the research effort along the French coasts, Figure 2 gives the number of species new to science described between 1945 and 2004, and new species records during the same dates in each area. Species new to science were described particularly in four areas: LR, PA, BA and RO. New species records were important also in these four areas plus the SBB area (presence of the Arcachon Marine Station).

- The large number of endemic species found in the bathyal and abyssal depths of the Bay of Biscay may be correlated with numerous previous deep-sea research cruises in this area relating to the Cap Ferret and Cap Breton canyons). (see Bachelet et al., 2003 for similar results with amphipods showing the importance of bathyal amphipods- 131 species outof a total of 319 species in the southern Bay of Biscay).

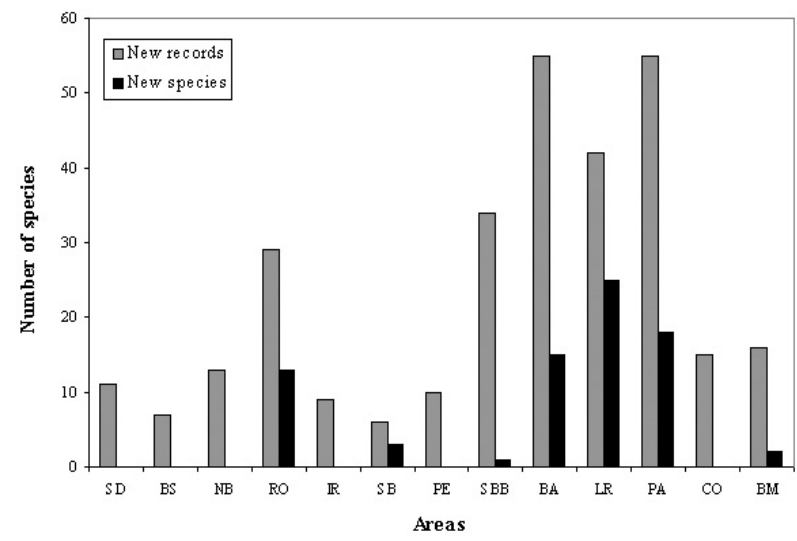

FIG. 2. - Number of species new to science described between 1945 and 2004, and new species records during the same period for each of the French geographic areas. [see Figure 1 for area codes].

- The increase in the number of species living on the continental shelf in the Provence-Côte d'Azur, Languedoc-Roussillon and South Biscay areas could be due to the presence of an extended bathyal zone, where species common to both the bathyal and the continental shelf zones live.

- Polychaete biodiversity appears to be linked to habitat diversity, which may account for the high numbers of polychaete species recorded in the Provence-Côte d'Azur (47 habitats), LanguedocRoussillon (46 habitats), and Roscoff areas (42 habitats). However, the polychaetes in the northern areas of the Bay of Biscay, Iroise Sea (46 habitats) and Southern Brittany (54 habitats) should be more diversified, thus reinforcing the necessity to increase the research effort in these areas.

- The hydro-climatic gradient of the different water masses may affect species richness. For example, in the western part of the English Channel, mild climate conditions prevail, with sea temperatures varying between $\cong 8^{\circ} \mathrm{C}$ in winter and $\cong 16^{\circ} \mathrm{C}$ in summer, whereas in Atlantic waters and eastwards in the Channel, there are larger temperature differences between winter $\left(\cong 5^{\circ} \mathrm{C}\right)$ and summer $\left(\cong 20^{\circ} \mathrm{C}\right)$. This may explain why polychaete species richness exceeds 400 in the Roscoff area, while remaining impoverished in the Bay of Seine (213) and the Strait of Dover (224).

A Bray-Curtis similarity analysis of the data (13 areas and 934 species) identifies four main polychaete groups (Fig. 3): 1) an English Channel cold temperate fauna, 2) an Atlantic warm temperate fauna, 3) a Mediterranean sub-tropical fauna, and 4) a bathyal fauna found in the Atlantic and Mediterranean bathyal zones. 


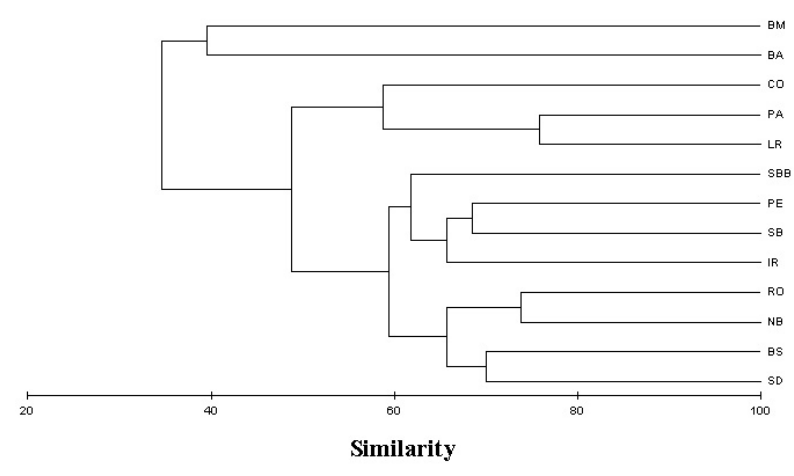

FIG. 3. - Results of a Bray-Curtis similarity analysis of the 934 polychaete species recorded in the 13 French geographic areas. [see Figure 1 for area codes].

- The English Channel cold temperate fauna can be separated into two groups: an eastern sector composed of two areas (BS and SD) with 153 shared species, and a western sector also composed of two areas (RO and NB) with 252 shared species. All four Channel areas share 130 species.

- The Atlantic warm temperate fauna lives on the continental shelf, and can also be divided into two subgroups: a southern sector (SBB) and a northern sector that comprises 3 areas (IR, SB and PE) with 128 shared species. SB and PE, two of the northern sector areas, share 180 species. These four Atlantic areas share 115 species.

- The Mediterranean sub-tropical fauna also lives on the continental shelf. More similarities exist between the areas PA and LR (375 shared species) than for either with $\mathrm{CO}$, although these three Mediterranean areas share a total of 197 species.

- The bathyal fauna is found in the Atlantic and Mediterranean bathyal zones; these zones share only 96 species.

The Channel and the Atlantic Ocean areas share 66 species, and the continental shelf areas share a total of 34 species. Eighteen species ( $\cong 1 \%$ of the total number of species) are common to all areas. As a consequence of the number of shared species between the shelf areas and their subgroups, the similarity between the two-bathyal zones is particularly low $(<40 \%)$. The similarities between continental shelf areas are higher than $60 \%$; they reach $75 \%$ between the two Mediterranean areas PA and LR and are $\geq 70 \%$ between the eastern zones (BS and $\mathrm{SD}$ ) or the western areas (RO and $\mathrm{NB}$ ) of the Channel.

The parsimony analysis of 934 characters (species) and 13 OTUs (zones), plus an out-group containing no species, produces a consensus tree

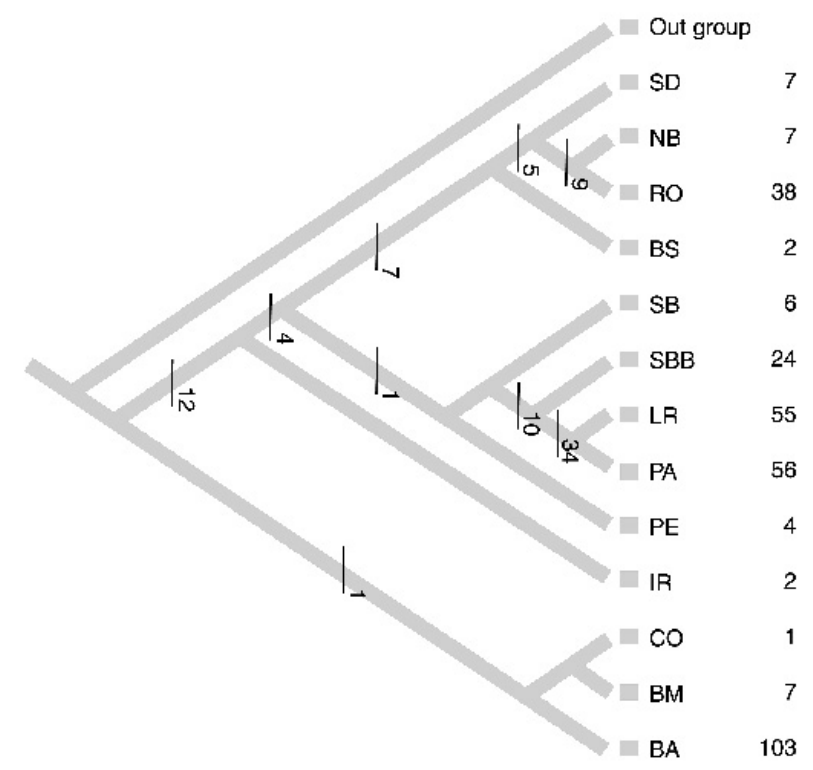

FIG. 4. - Strict consensus tree of the 934 characters (polychaete species) recorded in the French waters and the 13 OTUs (geographic areas). The number on the branch indicates the number of shared species in each monophyletic group, and the number over the zone name indicates the number of endemic species in each zone (see Figure 1 for area codes).

with a consistency index (CI) of 0.51 , which is high, given the number of characters (species) in the matrix. As shown in Figure 4, this consensus tree rooted with the out-group has two main branches: (1) $\mathrm{BM}+\mathrm{CO}$ and $\mathrm{BA}$, and (2) the remaining areas. The second branch can in turn be divided into three main subgroups: (i) the Iroise Sea (IR); (ii) the three remaining Atlantic areas $(\mathrm{SB}+\mathrm{PE}+\mathrm{SBB})$, together with the Mediterranean continental shelf areas (PA and LR); and (iii) the four Channel areas. The first branch (BM + CO and BA) has only one common species, which is not present in the other areas. But the research effort for Corsica is lower than for those of the two other Mediterranean areas; in fact, most of the available data for Corsica came from circalittoral and bathyal depths (Bellan, 1960; Carpine, 1970). This accounts for the connection of Corsica with the bathyal zones. Twelve species are shared by all other continental shelf areas, except $\mathrm{CO}$, and are not found in the $\mathrm{BM}+\mathrm{CO}$ and BA branch. Seven species are found exclusively in the Channel areas, and 34 are found only in the PA and LR areas. These two Mediterranean areas share 10 of their exclusive species with the SG area. Five species are found only in the subgroup, $\mathrm{SD}+\mathrm{NB}+\mathrm{RO}$, though the $\mathrm{NB}$ and $\mathrm{RO}$ areas have 9 exclusive species. 


\section{Biogeography of the different groups of polychaetes living in French waters}

The French polychaete fauna is composed of 17 species categories with a diverse biogeographic distribution. Brief descriptions of these categories are presented below, including the total number of species and the names of the characteristic species.

Species found exclusively on the continental shelf (0-200 m) (544 species, including 202 species found in only one zone of the 11 continental shelf areas)

- Arctic-boreal and cold temperate species present only in the eastern part of the English Channel. Only 2 species (Phyllodoce rosea and Neanthes virens) are present in both eastern Channel zones; 9 other species are present in only one zone.

- Arctic-boreal and cold temperate species present only in the English Channel: 70 species, including 38 species found only in the Roscoff area, 7 species found only in the Normano-Breton Gulf, and 25 species which can be found throughout the Channel (e.g. Autolytus alexandri, Malmgreniella arenicolae, M. marphysae) or only in the western part of it (e.g. Eulalia mustela, E. ornata); 5 other species are found only in the Channel and the Iroise Sea (e.g. Autolytus brachycephalus, Streptosyllis websteri), and two others are found only in the Iroise Sea.

- Arctic-boreal and cold temperate species present in the English Channel and Southern Brittany, but absent in the southern part of the Bay of Biscay: 9 species (e.g. Gattyana cirrhosa, Neoamphitrite figulus, Hipponoe gaudichaudi); 10 other species are found only in SB or PE.

- Cold temperate species present in the English Channel and the Bay of Biscay and absent in the Mediterranean: 34 species (e.g. Travisia forbesi, Pholoe balthica, Lepidonotus squamatus, Spirorbis spirorbis, Magelona filiformis); 7 species are present only in the Bay of Biscay (e.g. Aponuphis grubei, Ophelia limacina, Polydora cornuta) and 24 species are endemic to the southern Bay of Biscay.

- Warm temperate species endemic to the Mediterranean: 173 species, including 112 species found only in one of the three continental shelf areas, and 61 species found in two or three of these areas (e.g. Euclymene palermitana, Scolaricia typica, Ceratonereis costae).
- Warm temperate species present in the Mediterranean and in the southern Bay of Biscay: 17 species (e.g. Aponuphis brementi, Euchone rosea, Eclysippe vanellii).

- Warm temperate species present in the Mediterranean and along the French coast of the Bay of Biscay, but absent in the northern part of the Iroise Sea: 14 species (e.g. Eunice torquata, Magelona wilsoni, Eupanthalis kinbergi).

- Warm temperate species present in the Mediterranean and along the French Atlantic coast to the Roscoff area: 23 species (e.g. Aponuphis bilineata, Lepidonotus clava, Claparedepelogenia inclusa, Ophelia bicornis bicornis).

- Warm temperate species present in the Mediterranean and along the French Atlantic coast to the Normano-Breton Gulf, and absent in the eastern part of the Channel: 20 species (e.g. Armandia polyophthalma, Typosyllis amica, Sabellaria alveolata, Terebella lapidaria, Piromis eruca).

- Species with a large biogeographic distribution present in all French shelf areas: 115 species, including 13 species found in the 11 continental shelf areas (Euclymene oerstedi, Glycera fallax, Psamathe fusca, Perinereis cultrifera, Phyllodoce laminosa).

Exclusively bathyal species $(0-200 \mathrm{~m})(116$ species $)$

- Species present in the Mediterranean and Atlantic bathyal zones: 6 species (e.g. Pseudocapitella incerta, Peocilochaetus fulgoris).

- Species endemic to the Mediterranean: 7 species (e.g. Lacydonia laureci, Macellicephala laubieri).

- Species endemic to the Bay of Biscay: 103 species (e.g. Ophryotrocha geryonicola, Paradiopatra capbretonensis).

Species present on the continental shelf and at bathyal depths (274 species)

- Species endemic to the Mediterranean: 19 species (e.g. Aricidea annae, A. monicae, Phyllo kupfferi).

- Species present only along the Atlantic coast: 19 species (e.g. Phyllodoce groenlandica, Alentia gelatinosa, Neoamphitrite edwardsi).

- Coastal and deep-water species in the Mediterranean, which are strictly bathyal in the Bay of Biscay: 14 species (e.g. Rhodine loveni, Trachytrypane jeffreysii, Omphalopomopsis fimbriata, Anobothrus gracilis). 
TABLE 2. - Numbers (N) of polychaete species in different areas of the world's oceans.

\begin{tabular}{|c|c|c|}
\hline Areas & Authors & $\mathrm{N}$ \\
\hline Estuary and Gulf of Saint Lawrence & Brunel et al., 1998 & 293 \\
\hline Norwegian coasts & Holthe and Brattegard, 1997 & 595 \\
\hline North and Baltic Seas & Hartmann-Schröder, 1996 & 558 \\
\hline English Channel & This study & 495 \\
\hline Bay of Biscay & This study & 754 \\
\hline Iroise Sea & This study & 195 \\
\hline French Atlantic and Channel continental shelf & This study & 555 \\
\hline Mediterranean continental shelf & This study & 623 \\
\hline Gulf of Lions & This study & 641 \\
\hline Total French waters & This sudy & 934 \\
\hline Western Iberian coasts & This study & 661 \\
\hline Greek waters & Simboura and Nicolaidou, 2001 & 714 \\
\hline Italian waters & Castelli et al., 1995 & 800 \\
\hline European waters & Bellan, 2001 & 1848 \\
\hline Red Sea & Wehe and Fiege, 2002 & 567 \\
\hline Arabian Gulf & Wehe and Fiege, 2002 & 231 \\
\hline Gulf of Aden & Wehe and Fiege, 2002 & 177 \\
\hline Arabian Sea & Wehe and Fiege, 2002 & 141 \\
\hline Gulf of Oman & Wehe and Fiege, 2002 & 60 \\
\hline South African region & Day, 1967a, b & 800 \\
\hline Australian waters & Glasby et al., 2000 & 1140 \\
\hline Gulf of Mexico & Uebelacker et al., 1984 & 593 \\
\hline Coastal regions of California & Blake and Hilbig, 1994; Blake et al., 1995, 1996, 2000 & 445 \\
\hline Far eastern seas of Russia, NW Pacific & Ushakov, 1965 & 400 \\
\hline
\end{tabular}

- Species with a large biogeographic distribution present in the Mediterranean Sea, Atlantic Ocean and English Channel: 222 species, including 18 species found in all 13 areas (e.g. Notomastus latericeus, Scoloplos armiger, Terebellides stroemi, Aphrodita aculeata, Sabella pavonina).

\section{CONCLUSIONS}

There are no reliable data available concerning the number of polychaete species and their distribution worldwide, and to date, detailed faunistic studies have been done for only a few marine regions. (see Wehe and Fiege, 2002.) According to Glasby et al. (2000) the number of polychaete species worldwide is about 8500 spread over 1100 genera. Based on this estimate, about $11 \%$ of the known polychaete species can be found in French territorial waters (934 species). Although a strictly quantitative comparison of different fauna groups should be based on similar conditions in terms of biotope size, structure, and ecological requirements, which is not the case here, the polychaete fauna of the French waters appears to be one of the richest in terms of absolute species number (Table 2). There are, for example, twice as many species as in the Arabian region, which was judged by Wehe and Fiege (2002) to be among the richest regions for polychaetes. The diversity of polychaetes in French waters is of the same order of magnitude as in Australian waters (Glasby et al., 2000). At this scale of comparison, the polychaete fauna in the Bay of Biscay and along the French Mediterranean coastline appears among the most diverse. In the same way, the English Channel appears to be particularly rich (6\% of the known species). Thus, though it extends over only $10^{\circ}$ of latitude, the French coastline hosts $66 \%$ of the species recorded in the North East Atlantic over a $50^{\circ}$ range in latitude $\left(30^{\circ} \mathrm{N}-80^{\circ} \mathrm{N}\right)$. This is probably due to its intermediate latitudinal position, which encompasses both a boreal fauna and a warm temperate and sub-tropical fauna, thereby constitutes a biogeographic crossing in the temperate Lusitanian biogeographic zone corresponding to the warm temperate Mediterranean - Atlantic province of Briggs (1974).

Future research in this field should (1) increase the sampling efforts in certain French coastal zones-around Corsica, in the Iroise Sea and in the bathyal depths of the Mediterranean Sea, for example-where our knowledge of polychaete diversity appears insufficient, and (2) extend the comparisons of French polychaete faunas to other regions of the Atlantic. The latter objective should provide additional information about the affinities of the polychaete fauna and about their colonization of this ocean. 


\section{ACKNOWLEDGEMENTS}

The authors are grateful to Nicolas Desroy for his help with the similarity analysis and to Chris Glasby and another anonymous referee for their very useful comments on the first version of this paper.

\section{REFERENCES}

Bachelet, G., J.C. Dauvin and J.C. Sorbe. - 2003. An updated checklist of marine and brackish water Amphipoda (Crustacea: Peracarida) of the southern Bay of Biscay (NE Atlantic). Cah. Biol. Mar., 44: 121-151.

Bellan, G. - 1960. Annélides Polychètes récoltées au cours de sa campagne. $\mathrm{II}^{\circ}$ Campagne méditerranéenne par le 'Président Théodore Tissier'. Rev. Trav. Inst. Pêches Marit., 24: 273-292.

Bellan, G. - 2001. Annelida Polychaeta. In: Costello M.J., C.S Emblow and R. White (eds.), European Register of Marine Species. A check-list of the marine species in Europe and a bibliography of guides to their identification, pp. 214-231. Patrimoine Naturels, 50. Publications Scientifiques du MNHN, Paris.

Blake, J.A. and B. Hilbig. - 1994. Taxonomic atlas of the benthic fauna of the Santa Maria Basin and Western Santa Barbara Channel. The Annelida part 1. Polychaeta: Phyllodocida (Phyllodocidae to Paralacydoniidae). Santa Barbara Museum of Natural History, Santa Barbara, 4: 1-377.

Blake, J.A., B. Hilbig and P.H. Scott. - 1995. Taxonomic atlas of the benthic fauna of the Santa Maria Basin and Western Santa Barbara Channel. The Annelida part 2. Polychaeta: Phyllodocida (Syllidae and scale-bearing families), Amphinomida, and Eunicida. Santa Barbara Museum of Natural History, Santa Barbara, 5: 1-378.

Blake, J.A., B. Hilbig and P.H. Scott. - 1996. Taxonomic atlas of the benthic fauna of the Santa Maria Basin and Western Santa Barbara Channel. The Annelida part 3. Polychaeta: Orbiniidae to Cossuridae. Santa Barbara Museum of Natural History, Santa Barbara, 6: 1-418.

Blake, J.A., B. Hilbig and P.V. Scott. - 2000. Taxonomic atlas of the benthic fauna of the Santa Maria Basin and the Western Santa Barbara Channel. The Annelida Part 4. Polychaeta: Flabelligeridae to Sternaspidae. Santa Barbara Museum of Natural History, Santa Barbara, 7: 1-348.

Briggs, J.C. - 1974. Marine Zoogeography. Mc Graw-Hill Book Co., New York, USA.

Brunel, P., L. Bossé and G. Lamarche. - 1998. Catalogue des Invertébrés marins de l'estuaire et du golfe du Saint-Laurent. Publ. Spéc. Can. Sci. Halieut. Aqua., 126: 1-405.

Carpine, C. - 1970. Ecologie de l'étage bathyal dans la Méditerranée occidentale. Mém. Inst. Océanogr. (Monaco), 2 : $1-146$.

Castelli, A., M. Abbiati, F. Badalamenti, C.N. Bianchi, M.C. Gambi, A. Giangrande, M.F. Gravina, P. Lanera, C. Lardicci, A. Somaschini and P. Sordino. - 1995. Annelida Polychaeta, Pogonophora, Echiura, Sipuncula. In: A. Minelli, S. Ruffo and S. La Posta (eds.), Checklist delle species della fauna italiana, 19 , pp. 1-45, Bologna (Calderini), Italy.

Clarke, K.R. and R.M. Warwick. - 1994. Changes in marine communities: an approach to statistical analysis and interpretation. Plymouth Marine Laboratory, Plymouth.

Cracraft, J. - 1994. Species diversity, biogeography, and the evolution of biotas. Amer. Zool., 34: 33-47.

Dauvin, J.-C., G. Bellan, D. Bellan-Santini, A. Castric, J. ComoletTirman, P. Francour, F. Gentil, A. Girard, S. Gofas, C. Mahé, P. Noël and B. de Reviers. - 1994. Typologie des ZNIEFF-Mer, liste des paramètres et des biocénoses des côtes françaises mét-

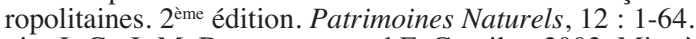

Dauvin, J.-C., J.-M. Dewarumez and F. Gentil. - 2003. Mise à jour de la liste des espèces d'Annélides Polychètes présentes en Manche. Cah. Biol. Mar., 44: 67-95.

Dauvin, J.-C. and D. Bellan-Santini. - 2004. Biodiversity and the biogeographic relationships of the Amphipoda: Gammaridea on the French coastline. J. Mar. Biol. Ass. U.K., 84: 621-628.

Day, J.H. - 1967a. A monograph on the Polychaeta of Southern Africa Part I. Errantia. Trustees of the British Museum (Natural History), London.

Day, J.H. - 1967b. A monograph on the Polychaeta of Southern Africa Part II. Sedentaria. Trustees of the British Museum (Natural History), London.

Desroy, N. - 1999. Les peuplements benthiques de substrats meubles du bassin maritime de la Rance. Evolution de la biodiversité et effets de l'activité prédatrice de Nephtys hombergii (Annélide, Polychète) sur le recrutement. Ph. D. thesis, Univ. Rennes I.

Fauchald, K. and G.W. Rouse. - 1997. Polychaete systematics: past and present. Zool. Scr., 26: 71-138.

Fauvel, P. - 1923. Polychètes errantes. Faune de France, 5. P. Lechevalier, Paris.

Fauvel,P. - 1927. Polychètes sédentaires. Addenda aux errantes, archiannélides, myzostomaires. Faune de France, 16. P. Lechevalier, Paris.

Fauvel, P. - 1930. Annélides polychètes de Nouvelle-Calédonie, recueillies par Mme A. Pruvot-Fol en 1928. Arch. Zool. Exp. Gén., 69: 501-562.

Fauvel, P. - 1952. Annèlides Polychètes recueillies aux Iles Kerguelen

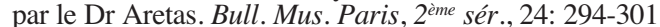

Glasby, C.J., P.A. Hutchings, K. Fauchald, H. Paxton, G.W. Rouse, C. Watson Russell and R.S. Wilson. - 2000. Class Polychaeta. In: P.L. Beesley, G.J.B. Ross and C.J. Glasby (eds.), Polychaetes and Allies. The southern synthesis. Fauna of Australia. Vol. 4 A. Polychaeta, Myzostomida, Pogonophora, Echiura, Sipuncula, pp. 1-296. CSIRO Publishing, Melbourne.

Hansson, H.G. (comp.)- 1998. NEAT (North East Atlantic Taxa): South Scandinavian marine Annelida check-list. Internet pdf [http://www.tmbl.gu.se].

Hartmann-Schröder, G. - 1996. Annelida, Borstenwürmer, Polychaeta. Die Tierwelt Deutschlands 58. Gustav Fischer Verlag, Jena.

Holthe, T. and T. Brattegard. - 1997. Class Polychaeta (phylum Annelida). In: T. Brattegard and T. Holthe (eds.), Distribution of marine, benthic macroorganisms in Norway. A tabulated catalogue, pp. 1-409. Preliminary Edition. Research Report for Directorate for Nature Management.

Lambshead, P.J.D. and G.L.J. Paterson. - 1986. Ecological cladistics. An investigation of numerical cladistics as a method for analysing ecological data. J. Nat. Hist., 20: 895-909.

Maddison, W.P. and D.R. Maddison. - 1992. MacClade version 3.0.1. A phylogenetic computer program distributed by the authors. Sinauer Ass. Inc., Sunderland, Mass.

Rouse, G.W. and K. Fauchald. - 1997. Cladistics and polychaetes. Zool. Scr., 26: 139-204.

Ruellet, T. - 2004. Infestation des coquilles d'huître Crassostrea gigas par les polydores en Basse Normandie: recommandations et mise au point d'un traitement pour réduire cette nuisance. $\mathrm{Ph}$. D. thesis, Univ. Caen.

Simboura, N. and A. Nicolaidou. - 2001. The Polychaetes (Annelida, Polychaeta) of Greece: cheklist, distribution and ecological characteristics. Monographs on marine Sciences, Scientific Publication of the National Centre for Marine Research, Athens.

Swofford, D.L. - 1993. P.A.U.P.: phylogenetic analysis using parsimony, version 3.1.1. Computer program distributed by the Illinois Natural History Survey, Champaign, Illinois.

Uebelacker, J.M. and P.G. Johnson. - 1984. Taxonomic guide to the polychaetes of the Northern Gulf of Mexico. 7 volumes. Barry A. Vittor and Associates, Inc., Mobile, Alabama.

Ushakov, P.V. - 1965. Polychaeta of the far Eastern Seas of the U.S.S.R. Keys to the fauna of the U.S.S.R. published by the Zoological Institute of the Academy of Sciences of the U.S.S.R (Pavlovskii, E.N. (ed.) 56: 419 p. Jerusalem, Israel Program for Scientific Translations).

Wehe, T. and D. Fiege. - 2002. Annotated checklist of the polychaete species of the seas surrounding the Arabian Peninsula: Red Sea, Gulf of Aden, Arabian Sea, Gulf of Oman, Arabian Gulf. Fauna of Arabia, 19: 7-238.

Received July 9, 2004. Accepted May 11, 2005. 